\title{
CHANGES IN HOUSEHOLD FORMATION AND COMPOSITION IN CHINA SINCE THE MID-TWENTIETH CENTURY
}

\author{
Zhongwei Zhao, ${ }^{\dagger}$ The Australian Demographic and Social Research Institute, \\ The Australian National University \\ Wei Chen, Center for Population and Development Studies, Demography \\ Department, People's University of China
}

\begin{abstract}
China has experienced great changes in household formation and composition since the mid-twentieth century, and its mean size of households has fallen from 5.4 persons in 1947 to 3.1 in 2005. Many of these changes, especially those taking place in the early years of the People's Republic, have not been systematically investigated. This paper examines the impact of China's major political, social, demographic and economic changes on household formation and composition. The study shows that changes in Chinese households have not followed a simple linear trajectory, but shown considerable fluctuations. A drastic increase in the number of households and a sharp reduction in the mean size of households were recorded after the land reform in the early 1950s. In the next twenty years, high fertility was promoted by a generally pronatalist environment, and the mean size of households increased. Since the early 1970s, the nationwide family planning campaign has led to a rapid fertility decline and great changes in kinship structure. The recent rise in rural-urban migration has also resulted in many unprecedented changes, and they have become major forces affecting household formation and family life in contemporary China.
\end{abstract}

Keywords: household formation, household composition, mean size of households, land reform, pronatalist environment, family planning, fertility decline, rural-urban migration, kinship structure, computer simulation

Traditional Chinese families and households are frequently placed at an extreme in the spectrum of world family systems and used as the example of large, multigenerational and complex residential groups found in the world. ${ }^{1}$ Studies however have shown that residential behaviour in historic China was more complicated than has often been portrayed. There were marked variations in household formation and composition both across regions and among different social groups. Despite such diversity, which was not surprising for a vast country, available evidence has

\footnotetext{
${ }^{+}$Address for correspondence: The Australian Demographic and Social Research Institute, The Australian National University, Canberra ACT 0200, Australia. Email: Zhongwei.Zhao@anu. edu.au.
} 
confirmed that historical Chinese households were generally larger in size and more complex in structure than their counterparts in many parts of the world (Lang 1946; Cohen 1976; Freedman 1979; Wolf and Huang 1980; Lee and Gjerde 1986; Lee and Campbell 1998; Wang, Y. 2000).

Great changes in household formation and composition took place in China in the second half of the twentieth century. According to available national statistics, the mean size of Chinese households first fell sharply from 5.4 persons per household in 1947 to 4.3 in 1953, and then increased gradually (except for a few years in the early 1960s) to 4.8 in the first half of the 1970s. After that it started a secular decline and reached 3.1 in 2005 (Ma 1988; Zhao 1993; National Bureau of Statistics 2006). These changes were closely related to the extraordinary political, social, economic and demographic transformations taking place in China in the last six decades.

Since the founding of the People's Republic, the Chinese population has experienced profound political and social changes, radical economic reform and restructuring, and unprecedented demographic transition: land reform, the adoption of a central planned economy, the formation of people's communes, the Cultural Revolution, the family-planning campaign, and the recent economic reform and rapid economic development. These events have greatly changed Chinese society, and strongly influenced people's family life and the formation of their households. Despite their significance for our understanding of the Chinese society, many of these issues have not been adequately examined.

This paper intends to fill some of these gaps. Based on available data, especially those collected at the national level, it investigates a number of questions that have hardly been studied before. Rather than conducting a systematic review of changes in household formation and composition and all their determinants, the paper concentrates on the impact of China's great political, social, economic and demographic changes on household structure and people's residential behaviour. Following this brief introduction, the first section examines the impact of land reform on household formation. The second section discusses the increase in mean size of households in the pronatalist environment of the 1950s and 1960s. The next section, through the use of computer microsimulation, investigates the influence of low and very low fertility on kinship structure and co-residential patterns. The fourth section studies changes in household structure in the process of rapid increase of migration, and the last section draws some conclusions.

\section{The land reform and the rapid reduction in the mean size of households}

Figure 1 graphically presents changes in the mean size of households in China in recent history. According to limited national statistics, the mean size of Chinese households fluctuated at around 5.3 persons per household in the first half of the twentieth century. In 1947, two years before the founding of the People's Republic, the national population was 463.2 million, the total number of households was 86.6 million, and the mean size of households was 5.4 persons (Ma 1988; Zhao 1993). These national figures were largely consistent with those obtained from in-depth investigations conducted by various scholars. For example, Collections of Social Surveys in the Republic Period (Population Volume) reprinted 23 survey reports and research papers published before 1950 and many of them provided information on household composition at the time. According to 13 studies undertaken in Beijing, Nanjing, Hebei, 
Figure 1 Changes in the mean size of households in China, 1911-2005

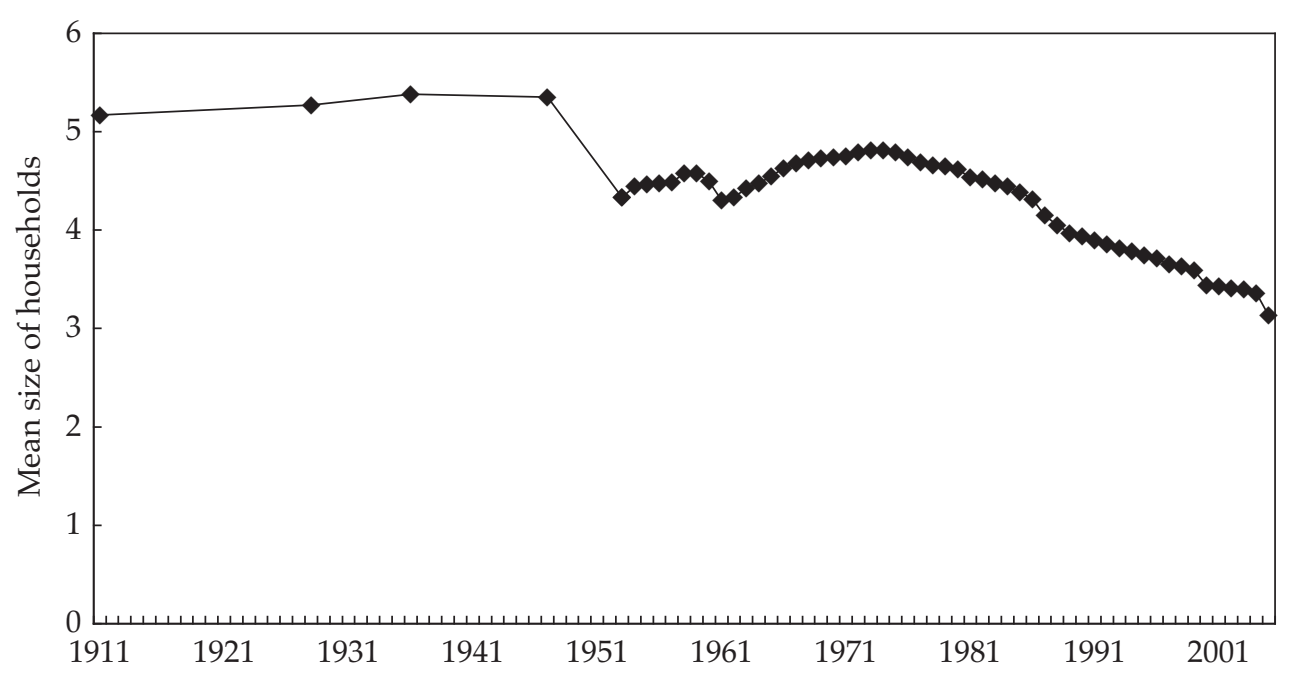

Sources: Ma 1990; Editorial Committee of Almanac of China's Population 2005, 2006; National Bureau of Statistics 2006

Shanxi, Shandong, Guangdong and Fujian between the mid-1920s and the early 1940s, the mean size of households in all populations being studied was 5.2 persons (Li et al. 2004). ${ }^{2}$

One of the most striking changes shown in Figure 1 is the drastic decrease in average household size, from 5.4 to 4.3, over the period between the late 1940s and early 1950s. ${ }^{3}$ By 1953, China's total number of households had reached 135.8 million: an increase of 57 per cent since 1947 or an annual growth of 7.8 per cent for six years. During this period, the increase in households far exceeded the growth of population and the mean size of households fell by 20 per cent. These changes were related to factors such as the improvement made in registration and data collection, the increase of geographic areas controlled by the central government, and a large number of retired officers and discharged soldiers settling in other places rather than returning to their hometowns; but a major driving force for these great transformations was the land reform, which started in 1949 or 1950 and ended in 1952 in most areas (Liu 1950; Liao 1952).

Before land reform, most arable land was owned disproportionately by a small number of landlords and rich peasants in many areas. The majority of the Chinese population consisted of poor peasants and landless labourers. The primary object of land reform was, through redistribution of land, to eliminate large land ownership and the exploitation based on such ownership, and to reduce the differentials between the rich and the poor which were closely related to the amount of land possessed. ${ }^{4}$ This radical reform undoubtedly encountered the resistance of those whose interests were at stake and soon became a large-scale political campaign. During this campaign, most of the land that was formerly owned by landlords (and often with their houses or other properties) was confiscated and redistributed among poor peasants. The landlords were severely denounced, punished and in some cases even 
Table 1 Mean size of households by social class in China

\begin{tabular}{|c|c|c|c|c|c|c|c|c|}
\hline Places & Years & $\begin{array}{c}\text { Farm } \\
\text { labourers }\end{array}$ & $\begin{array}{c}\text { Poor } \\
\text { peasants }\end{array}$ & $\begin{array}{l}\text { Middle } \\
\text { peasants }\end{array}$ & $\begin{array}{l}\text { Well- } \\
\text { to-do } \\
\text { peasants }\end{array}$ & $\begin{array}{l}\text { Land- } \\
\text { lords }\end{array}$ & Others & $\begin{array}{l}\text { Number } \\
\text { of house- } \\
\text { holds }\end{array}$ \\
\hline $\begin{array}{l}\text { North } \\
\text { China }\end{array}$ & $1930 \mathrm{~s}$ & 4.3 & 5.1 & 6.9 & 7.5 & 8.9 & -- & 458 \\
\hline Jianning & 1931 & 4.6 & 4.8 & 5.8 & \multicolumn{2}{|c|}{6.4} & -- & 480 \\
\hline Longyuo & 1934 & 2.9 & 5.4 & 5.9 & 7.8 & 8.0 & 4.0 & 318 \\
\hline Yongjia & 1934 & 2.7 & 4.4 & 6.4 & 6.3 & 11.8 & 3.6 & 292 \\
\hline Dongyang & 1934 & 3.2 & 4.3 & 5.5 & 7.8 & 11.0 & 3.3 & 329 \\
\hline Chongde & 1934 & \multicolumn{2}{|c|}{4.5} & 5.0 & 6.7 & 7.3 & 2.3 & 399 \\
\hline China & 1954 & \multicolumn{2}{|c|}{4.2} & 5.0 & 6.2 & 4.2 & 5.1 & 16,000 \\
\hline
\end{tabular}

Sources: Rural Reconstruction Committee of Administrative Council 1934; Lang 1946; Zhang 1931; Schran 1969.

executed. The land reform not only had a significant effect on China's political, social and economic development, but also resulted in great changes in Chinese households, as indicated by the data presented in Table 1.

In Chinese history, the size of a household was often positively related to its wealth, especially landholding; this remained largely unchanged in the first half of the twentieth century. As Table 1 shows, before land reform the mean size of households for the landlords and rich peasants was markedly larger than that for the middle and poor peasants. The possession of a large amount of wealth allowed the rural upper class to practice polygamy, have more children, and employ labourers or servants, and made it easier for them to maintain a large household. The size of middle peasants' households was at an intermediate level, and that of poor peasants and labourers was the smallest. This was partly related to the facts that mortality was often higher among the poor because of their lower living standards, and that some of their family members had to work elsewhere owing to their shortage of land. Similar observations were made by other researchers, but the data reported by them are not presented in Table 1 because of the difference in their classifications (Li 1933; Qiao 1931; Feng 1933; Wang 2003). ${ }^{5}$

Two major changes took place in or after the land reform. First, the mean size of landlords' households fell from being the largest to the smallest and the households of well-to-do peasants also shrank considerably. During the land reform, the large land owners had most of their land confiscated and this itself played an important role in reducing the size of their households. For example, in addition to the restriction imposed by laws or government regulations, a drastic decrease in landholding would make it difficult for the former landlord to employ servants and labourers. More importantly, however, land reform was not only an economic reform, but also a 'political struggle'. In this campaign, landlords were widely regarded as the 'class enemy' and deprived, partly or completely, of both their economic interests and their political rights. Under such circumstances, even a kin link with a landlord or a rich peasant could lead to a political danger or an economic loss for an individual. For 
this reason, many people split away from the households of their landlord parents or relatives to distance themselves from the 'exploiting classes'. This was thought to be the politically right thing to do and encouraged, although it was also used as a means of self-protection. Moreover, having received newly allocated land and houses, those who had previously worked as labourers or servants, and were attached to or lived in the household of landlords, broke away and formed their own households. All these tended to reduce the size of households belonging to former landlords. Similar changes took place in the households of well-to-do peasants, although they were less severely attacked than the landlords in general. These research findings and suggestions are highly consistent with those reported in an anthropological study conducted in north China by D. Wang (2000).

The households of the landlords and well-to-do peasants constituted only a minority in rural China. The division of their households alone was unlikely to cause a nationwide sharp increase in the number of households and decrease in mean household size. The second factor contributing to these changes was the large-scale household division taking place across all social classes. This was clearly related to and probably stimulated by certain land reform policies and practice. For example, when land was redistributed, it might be divided according to the number of people. But when houses were allocated, the unit of a household had to be taken into consideration. A solitary person, therefore, was more likely to get a larger share than he (or she) would if he (or she) co-resided with other people. In addition to that, some government policies were obviously in favour of single-person, or small, households. The Law of Land Reform of the People's Republic of China stipulated that when land was allocated, poor peasants who lived in households with only one or two persons could be given a larger share than they were entitled to, if this was permitted by conditions in the village and if those who would receive the land were able to cultivate it. ${ }^{6}$ Such a policy seems to have been widely implemented. In Beijing, for instance, the amount of land given to solitaries or households with only two persons was generally equal to that given to two or three persons who lived in larger households. Similar practices were also reported in other areas. ${ }^{7}$ Given that land and houses were so important to poor peasants, such policies and practices naturally encouraged people to divide their households. Furthermore, when those homeless or inadequately housed were given land and houses, it was often more convenient for them to live as separated households, particularly when their houses were far apart. All these inevitably led to a great increase in the number of households and a considerable fall in the mean size of households in the early 1950s. These conclusions are supported by the survey results reported by Wang, which show that after land reform, household structure became simpler than before in the villages studied by him (Wang 2003).

\section{Rising mean size of households in the pronatalist environment}

After land reform, changes in the number and mean size of Chinese households were less dramatic in general. As shown in Figure 1, the mean size of households increased slightly from 1953 to 1959, and then decreased to 4.1 by 1961 which was the lowest level recorded before the mid-1980s. From the early 1960s, the mean size of households rose steadily and reached 4.8 in 1974, which was the highest since 1953 . Two of these changes are worth further comment. First, the size of Chinese households displayed a general trend of increase between the early 1950s and the early 1970s. This 
seemed to contradict what had been predicted by many scholars who suggested that households would become smaller in size and simpler in structure during the process of industrialization and modernization. Second, there was a notable decline in the mean size of households in the early 1960s. These ups and downs, just like the drastic reduction in the mean size of households in the early 1950s, were closely related to the socio-economic changes taking place during the 1950s and 1960s.

It is noteworthy that during most of these two decades, the speed of population growth exceeded that of the number of households. This was closely related to the high fertility and falling mortality and contributed directly to the increase in household size. The high fertility observed in most of the 1950s was in part attributable to the postwar baby boom. As in many countries, the end of the war in the late 1940s led to a surge in marriage and childbearing in China. This, combined with the improvement in living standards and mortality, generated rapid population growth. Nonetheless, there were more important reasons for China's prolonged 'baby boom' and the increase in the mean size of households which lasted to the early 1970s. The pronatalist political ideology and economic system were among the most influential reasons.

China's political climate was generally favourable to childbearing and high fertility in most of the 1950s and 1960s. While modern birth control methods and family planning services were already available in the early 1950s, such provision was mainly due to health concern for mothers and their children. Since the mid-1950s, discussion of population issues had increased, and this was partly generated by the fact that the 1953 population census reported a larger than expected population total. In 1957, Ma Yinchu, a well-known economist, published his 'New Population Theory' and strongly promoted population control. However, the academic discussion and debate over population issues ended abruptly because of the intervention of the political leader. Ma's theory and the suggestion of controlling population growth were soon branded as Malthusianism and anti-socialist. As a result, the benefit of having a large population was overstated widely and the pronatalist ideology dominated official viewpoints on population issues for more than a decade. Sociology and population studies became 'forbidden areas', and were no longer taught in academic institutions until the early 1970s (Zha 1999; Zhai 2000).

China's socio-economic environment equally offered many incentives for high fertility during most of the 1950s and 1960s. Following the land reform, the Chinese government launched a series of campaigns to implement its collectivization plan in rural areas. This started with the introduction of the 'mutual help groups', which was followed by the formation of 'elementary' and then 'high level' agricultural co-operatives. By 1958, people's communes were established widely, and they remained in the place until the early 1980s. Under the commune system, the Chinese household was no longer a work group but primarily a unit of consumption and reproduction. The land and the farm machinery were owned collectively and all productive activities were organized by the production brigade or production team. Products and profits were distributed among all members according to both their membership and the amount of work they had completed within a certain period (normally one year). Major living necessities were usually provided to all villagers including children free of charge or at heavily subsidized price. This arrangement reached such an extreme in 1958 that 'public mass dining halls', which provided free meals to their members, were introduced in many communes. While these dining halls were short-lived, the 
nature of the collective distribution system did not change until the people's commune was dismantled two decades later. ${ }^{8}$ An economic system of this kind not only greatly reduced the cost of raising children, but also made them profitable from the time of their birth. ${ }^{9}$ It tended to encourage rather than to restrain high fertility. It was under such political and socio-economic circumstances that the Chinese population maintained a high speed of growth during most of the 1950s and 1960s. The mean size of households rose consistently and reached 4.8 persons in 1974 .

Another major reason that contributed to the high fertility and the increase in household size between the early 1960s and the early 1970s, and also to the marked fall in the mean size of households immediately before that time (which was very noticeable in Figure 1 and mentioned earlier) was the Great Famine. Between 1959 and 1961, China experienced severe food shortages throughout the country because of the failure of government policy and natural disaster. During this period, mortality rose sharply and fertility fell to a rather low level. As a result, the Chinese population decreased from 672.1 million to 658.6 million even according to official sources (Yao and Yin 1994). The famine generated considerable refugee migration. Many people left their homes and family members behind and moved to other areas to search for food and employment. Even the separation of husband and wife was not uncommon. Because of the increasing tension within families, which was largely caused by the difficult economic situation, the divorce rate and household fission, at least in some provinces, rose considerably. These factors contributed to the increase in the number of households and the reduction in the mean size of households during the early 1960s.

An important role played by the famine was to reinforce people's memory of the past when their goals of reproduction were frequently shattered by high mortality. In the 1950s, marked mortality reduction was already recorded in most parts of China and fertility decline also started in large cities, but the great mortality surge caused by the famine reminded the population that even in the 'new society', the destruction associated with high mortality could still take place. Under the high mortality like that experienced during the famine period, they might still need to maintain a high fertility in order to ensure at least one son surviving to adulthood. This was clearly a reason for the high fertility and the continuous increase in the mean size of households in the post-famine decade.

History could not repeat itself, which would otherwise allow these suggestions to be tested. It is, however, highly likely that if China's pre-1970s political ideology and socio-economic policies had been less favourable to high fertility, if the family planning program had not been interrupted by the anti-rightist campaign in the late 1950s and again by the social upheaval in the early years of the Cultural Revolution, and if the Great Famine had not taken place, the fall in fertility and in mean size of households could well have started earlier.

The above discussion concentrated largely on changes in the mean size rather than the composition of households, and this was mainly due to the constraint imposed by data availability. A recent retrospective survey has reported that household structure in the study area became simpler during the 1950s and 1960s. Although the mean size of households showed a general trend of increase at the national level, in most of the villages under investigation the proportion of joint-family households decreased, while the proportion of nuclear-family households and single-person households increased (Wang 2007). This nuclearization process was thought to be related to the 
following changes: the collectivization in rural areas, the loss of its land ownership and functions as a unit of production by the household, and the weakening of parental authority in the family. It was in this changing environment that China's traditional family system gradually lost its influence (Wang, D. 2000; Wang 2003, 2007).

\section{Rapid fertility decline and changes in kinship structure and household composition}

The early 1970s was an important turning point in China's demographic history, when fertility started to fall at an unprecedented speed. Largely driven by this change, the mean size of Chinese households also began its long-term decline, as shown in Figure 1.

China experienced a great improvement in survival in the 1950s and 1960s except during the Great Famine. Life expectancy at birth for the population increased from lower than 35 years in the first half of the twentieth century to 56 in 1957, 64 in the early 1970s and 68 in the year 1981 (Barclay et al. 1976; Banister 1987; Huang and Liu 1995). ${ }^{10}$ Since then, mortality has further improved and life expectancy has now risen to 73 years. China's remarkable success in lowering mortality and the high fertility in the 1950s and 1960s led to an extraordinary population growth, with a natural increase rate of more than two per cent for most of the years. By 1970, China's national population had already reached more than 800 million. Facing the increasing population pressure, the Chinese government launched a nationwide family planning campaign in the early 1970s and this led to a rapid fertility reduction. China's Total Fertility Rate (TFR), which was still around 6 children per woman when the campaign started, fell drastically to around 2.5 in 1980. In the following decade, the TFR fluctuated between 2.3 and 2.9 (Yao 1995). Further fertility decline became evident in the early 1990s when China's TFR fell to the level of below replacement. While there are some uncertainties about China's recent fertility levels, an increasing number of studies have shown that the TFR is most likely to have reached around 1.6 in the late 1990s and has stayed at this or a lower level since (Yu and Xie 2000; Guo 2004; Cai 2005; Retherford et al. 2005; Scharping 2005; Zhang and Zhao 2006). ${ }^{11}$

Fertility reduction of this magnitude has a profound influence on Chinese households. After reaching its recent peak in 1974, the mean size of Chinese households began a steady decline. By the late 1980s, it had already fallen to less than four persons. This was largely attributable to the reduction in the number of children present in the household. The rapid fertility decline also led to drastic changes in the availability of kin, and this has influenced and will continue to influence household formation in the population.

To examine the impact of falling fertility on kinship structure and household composition, CAMSIM, a computer microsimulation system developed by Smith and Oeppen was used in this study (Smith 1987; Smith and Oeppen 1993). Because the number and type of surviving kin available to each individual and the kinship structure in a society are primarily determined by levels and patterns of fertility, mortality and marriage, ${ }^{12}$ changes in kinship structure and their effect on potential co-residential patterns can be simulated on the basis of detailed information about these demographic factors. ${ }^{13}$

In this study, three different demographic scenarios were set up, and all of them used the same mortality and marriage schedules. In these simulations, the simulated 
population experienced mortality similar to that recorded in China in the late 1990s: life expectancy at birth was approximately 71 years (about 70 for males and about 73 for females). The overwhelming majority of those surviving to adult ages (97 per cent of men and 99 per cent of women) would marry. Input fertility rates for the three simulations were different, however. In the first simulation, the TFR was about 5.9, which was slightly higher than that found in many historical Chinese populations but close to that recorded in the 1950s and 1960s. In the second simulation, the TFR was close to 2.2, and it was the level of replacement under the given mortality. In the third simulation, the TFR was slightly above 1.6 and similar to that estimated for recent years. Hence, any difference in the availability of kin and potential co-residential patterns among three sets of simulation outcomes would result from their fertility differentials and random variations. The random variation can be reduced effectively through increasing the size of the simulated population. The effect of changing fertility can be studied accordingly.

In each of the three simulation runs, 5,000 male egos and their kin (great-grandparents, grandparents, parents, uncles, aunts, spouses, siblings, first cousins, children, nephews, nieces, grandchildren and great-grandchildren) were simulated. ${ }^{14}$ Table 2 shows mean numbers of surviving kin of given types for male population at selected ages, which were generated by CAMSIM under the three different demographic regimes specified above.

Since all simulation runs used the same mortality and marriage input parameters, mean numbers of surviving spouse for males were very close among the three sets of simulation results. They all started to increase when male egos were aged in their mid-20s, reached the peak in their 40s, and fell gradually thereafter. Although all three simulated populations experienced the same mortality, mean numbers of surviving parents, grandparents and great-grandparents were notably greater with replacement or below-replacement fertility than with high fertility. This was caused by their different fertility patterns. Under the high-fertility regime, women's reproduction lasted for a longer period and the average age difference between consecutive generations was greater than under the two low-fertility regimes. Therefore, the chance of children (mainly those born to older women) sharing lifetime with their parents, grandparents or great-grandparents was lower than under the low-fertility regime where most women completed their reproduction at earlier ages and the mean age of maternity was relatively low.

Under the high-fertility regime, simulated male egos naturally had a greater number of children and grandchildren than under the replacement or below-replacement regime. At age 70 for example, male egos living under the high-fertility regime had 5.7 surviving children and 14.5 surviving grandchildren. In contrast, the mean number of children was 2.1 and the mean number of grandchildren was 4.0 for those experiencing replacement fertility. The figures were even lower for those experiencing the below-replacement fertility regime, 1.5 children and 2.3 grandchildren. Another marked difference was observed in the mean number of kin extended laterally or diagonally. Under the high-fertility regime, male egos had a large number of siblings, uncles and aunts. Because of that, when they were aged 30 the mean number of their surviving first cousins reached more than 60, and when they were aged 70 the number of their surviving nephews and nieces reached more than 30 . Under the replacement or below-replacement fertility regimes, the number of siblings, uncles and aunts that male egos had was much smaller. This resulted in a great reduction 
Table 2 Mean number of surviving kin for males at selected ages

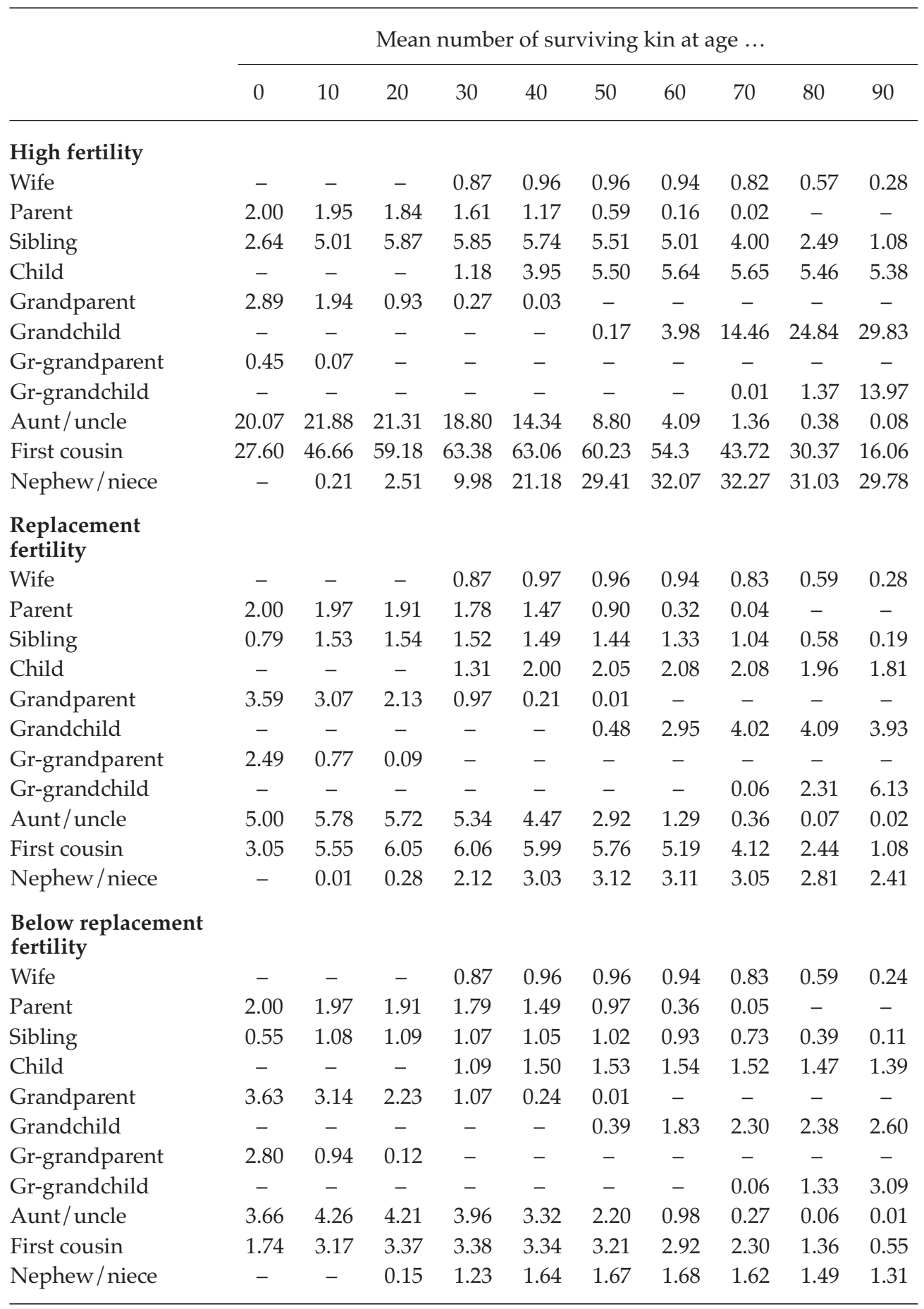

Source: Results generated by the computer simulation conducted by the authors. 
in the mean number of surviving first cousins, nephews and nieces. At age 30, male egos experiencing the replacement fertility had an average of six first cousins and those experiencing the below-replacement fertility had just over three first cousins. At age 70, the numbers of their surviving nephews and nieces were three (replacement fertility) and less than two (below-replacement fertility).

Great changes of this kind could have a significant impact on household formation and composition. This is indicated by the difference in proportions of male egos with surviving children and spouse, which were generated by the three simulation runs and are presented in Table 3. Under the high-fertility regime, forming a large joint family household could easily become a reality for most male egos. For example, nearly 90 per cent of those reaching age 70 had at least one surviving son and about two-thirds had two or more married sons. Those without surviving children and those who had neither surviving children nor surviving spouse accounted for slightly more than six per cent. With replacement fertility, the major changes were the decrease in the proportion of males with two or more married sons and the increase in the proportion of males without surviving sons. The proportion having at least one surviving son declined to about 70 per cent for those aged 70 and those with two or more married sons fell to a quarter. While those having no surviving sons increased to about 30 per cent, the proportion of those without surviving children and of those with neither surviving children nor spouse was similar to that under the high-fertility regime. With the below-replacement fertility specified in the study, the proportion of males having at least one surviving son and of those with two or more married sons further decreased. At age 70, those without surviving sons reached more than 40 per cent and fewer than 14 per cent had two or more married sons. The proportion of male egos without surviving children and those having neither surviving children nor surviving spouse rose to 11 per cent.

Because of China's great fertility reduction, forming a joint family household with two or more married sons will become increasingly difficult. In comparison with circumstances of high fertility and relatively low mortality, the chance of people living with their sons will decrease markedly. A growing number of old people will have to depend on their daughters to provide the needed family support. Under the below-replacement fertility regime similar to that specified in the third simulation, the proportion of old people who have no children will rise notably, and providing adequate support for them will become a challenge in the near future. Despite that, however, it is equally important to note that although China's fertility decline has significantly influenced and will continue to influence household formation and composition, under the replacement or even the below-replacement fertility specified in this study, the situation of family support for the elderly may not become worse than that in the past when both fertility and mortality were high. As shown in another study conducted by one of the authors, under the fertility and mortality similar to those existing in China before its demographic transition, the chance of old males living with their married sons was close to those simulated under the two low-fertility regimes as reported above; but because of the impact of severe mortality, the proportion of those having no surviving children and those without surviving children and spouse (in China's pre-demographic transition times) was considerably higher than that reported in this study (Zhao 1998). ${ }^{15}$ 
Table 3 Proportion of males having surviving kin of given types at selected ages

\begin{tabular}{|c|c|c|c|c|}
\hline & \multicolumn{4}{|c|}{ Proportion having surviving kin at age ... } \\
\hline & 50 & 60 & 70 & 80 \\
\hline \multicolumn{5}{|l|}{ High fertility } \\
\hline 2 or more married sons & 0.85 & 34.03 & 65.09 & 69.70 \\
\hline 1 married son & 7.82 & 30.89 & 19.16 & 16.12 \\
\hline 1 or more unmarried sons & 79.56 & 23.74 & 3.70 & 0.94 \\
\hline Having daughters but no son & 5.94 & 5.69 & 5.91 & 6.42 \\
\hline No children but having spouse & 2.94 & 2.77 & 2.53 & 2.07 \\
\hline No children and spouse & 2.89 & 2.89 & 3.61 & 4.75 \\
\hline \multicolumn{5}{|l|}{ Replacement fertility } \\
\hline 2 or more married sons & 1.34 & 18.75 & 25.00 & 22.47 \\
\hline 1 married son & 13.46 & 40.59 & 42.39 & 43.34 \\
\hline 1 or more unmarried sons & 55.34 & 10.73 & 2.84 & 2.00 \\
\hline Having daughters but no son & 22.96 & 22.83 & 22.55 & 24.40 \\
\hline No children but having spouse & 4.15 & 4.26 & 3.81 & 2.90 \\
\hline No children and spouse & 2.74 & 2.85 & 3.42 & 4.89 \\
\hline \multicolumn{5}{|l|}{ Below replacement fertility } \\
\hline 2 or more married sons & 0.87 & 10.41 & 13.44 & 13.28 \\
\hline 1 married son & 12.33 & 40.20 & 41.82 & 41.03 \\
\hline 1 or more unmarried sons & 46.22 & 8.48 & 2.91 & 2.04 \\
\hline Having daughters but no son & 30.75 & 30.73 & 30.43 & 29.45 \\
\hline No children but having spouse & 6.65 & 6.74 & 6.88 & 7.10 \\
\hline No children and spouse & 3.18 & 3.44 & 4.51 & 7.10 \\
\hline
\end{tabular}

a Those who have two or more married sons, one married son, or one or more unmarried sons may also have surviving daughters or a spouse. Similarly, those who have daughters but no son may also have a spouse.

Source: Results generated by the computer simulation conducted by the authors.

\section{Economic reform, increasing migration and their impact on co-residential patterns}

In addition to the sharp fertility decline, another significant factor that has greatly influenced household formation and composition in China in the last quarter of a century was the extraordinary increase of migration and floating population.

During most of the 1960s and 1970s, the Chinese government imposed a strict control over population movement. Internal migration was generally small in volume and negligible in most years. This began to change in the late 1970s when China started its radical economic reform, which brought about many drastic changes such as the unprecedented opening to the Western world, promoting foreign investment 
and joint ventures, relaxing government control of population mobility, and reforming housing policies in urban areas. These changes led to a great increase in migration. According to available statistics, the number of the floating population - those who lived outside the county where their household registration was kept - was rather small in the year 1980, but it increased rapidly over the next two and half decades and reached nearly 150 million in the year 2005. The floating population now accounts for more than 10 per cent of the national population (Zhongxishe 2006).

Migrants tend to be selective and China's floating population is no exception. According to the 2000 census, the majority of migrants were young and those aged between 15 and 34 made up more than 60 per cent of the total. The sex ratio of all migrants was just above 105, but it varied across ages. There were 85 or fewer males for 100 females among those aged 15-24, while there were 115 or more males for 100 females among those aged 30-54. Nearly 30 per cent of migrants who were aged 15 and above were never-married, which was notably higher than the 18 per cent recorded among rural residents and the 20 per cent recorded in the national population. Some 60 per cent of married migrants lived together with their spouses in the place of destination. A large migrant population with these characteristics inevitably had a great impact on household formation and composition.

China's great population movement has first of all created many migration-split households, which are operationally defined in this study as households (found mainly in the place of origin) that have some of their members living and working temporarily in other areas, or households (found mainly in the place of destination) that consist of temporary migrants who have some of their household members left behind in the place of origin. Because some migrants brought all their family members with them, migrant households in the place of destination could include some households that are not affected by the migration-related split. According to the 2000 census, such migration-split households were close to 70 million and accounted for 20 per cent of all households. The number of people who were affected by such migration-related separation could be as high as 300 million.

The increase in the number of migration-split households contributed to the decline in the mean size of households. As indicated by the 2000 census, the mean size of migration-split households was 3.27 persons in the place of origin, and the average number of people working outside as migrants in these households was 1.38 persons. If there were no migration and such migration-related split, the mean size of Chinese households would be larger than that recorded by the census which was 3.44. Because many migrants had left their parents, children, even spouses behind and moved to other places to work, the migration-split households, either those consisting of migrants themselves in the place of destination or those left behind in the place of origin by the migrants, tended to be 'incomplete' in structure in comparison with households that were not affected by such migration-related separation. This is evident from the results presented below.

Table 4 provides information on household composition in rural China in the year 2000. In comparison with households without their members living elsewhere, a larger proportion of households with migrants living in other places consisted of only one generation and a smaller proportion of these households consisted of two generations. A closer examination reveals that among households with migrants living elsewhere, the proportion of households that comprised two generations including a young couple (both under age 50) was only about half of the households which 
Table 4 Household composition in rural China, 2000

\begin{tabular}{lccc}
\hline & $\begin{array}{c}\text { Households } \\
\text { without } \\
\text { migrants living } \\
\text { elsewhere }\end{array}$ & $\begin{array}{c}\text { Households } \\
\text { with migrants } \\
\text { living } \\
\text { elsewhere }\end{array}$ & $\begin{array}{c}\text { All } \\
\text { households }\end{array}$ \\
\hline Household composition & & & \\
One generation & 18.7 & 24.7 & 20.1 \\
Two generations & 61.3 & 54.7 & 59.7 \\
$\quad$ Both husband and wife aged under 50 & 45.8 & 23.7 & 40.3 \\
Husband or/and wife aged 50 and over & 7.6 & 9.3 & 8.0 \\
Only one of the couple present & 5.5 & 13.5 & 7.5 \\
$\quad$ Grandparents with grandchildren & 0.8 & 6.3 & 2.2 \\
Others & 1.6 & 1.9 & 1.7 \\
Three generations & 19.4 & 19.7 & 19.5 \\
Four and more generations & 0.6 & 0.9 & 0.7 \\
Total & 100.0 & 100.0 & 100.0 \\
Household members per 100 households & & & \\
Household head & 100.0 & 100.0 & 100.0 \\
Spouse & 83.9 & 68.5 & 80.0 \\
Child and child-in-law & 143.2 & 114.2 & 135.9 \\
Parent and parent-in-law & 19.3 & 17.0 & 18.7 \\
Grandchild & 12.4 & 24.7 & 15.5 \\
Others & 5.3 & 8.2 & 6.0 \\
Total number of households & 147,443 & 49,561 & 197,004 \\
\hline
\end{tabular}

a Migrants were excluded in calculating these statistics.

Source: Computed from the 2000 census sample data.

had the same structure but without their members living in other places. Furthermore, among two-generation households which had migrants living elsewhere the proportion of those with only husband or wife present (single-parent family) or those consisting of grandparents and grandchildren (without the presence of the middle generation) was markedly greater than the proportion which did not have members living in other places. These differences were largely attributable to the fact that in households with migrants, many young couples or one of the couple moved into cities and left their children with grandparents or left their spouse and children behind. This is also indicated by the comparison of household members by kinship relation, which is shown in the lower panel of Table 4. In comparison with households without members living elsewhere, the average number of spouses per hundred households, in households with migrants living in other places, was considerably lower while the number of grandchildren was much higher. In households with migrants, the number of children and children-in-law was also relatively low. These observations are supported by other studies which show that the proportion of households 
Table 5 Residential patterns of surveyed migrants in Beijing, 2006

\begin{tabular}{lccc}
\hline Residential patterns & $\begin{array}{c}\text { All } \\
\text { migrants }\end{array}$ & $\begin{array}{c}\text { Married } \\
\text { migrants }\end{array}$ & $\begin{array}{c}\text { Married migrants } \\
\text { with children }\end{array}$ \\
\hline Living alone & 40.58 & 22.31 & 18.55 \\
Living with spouse & 45.29 & 64.15 & 66.14 \\
Living with children & 1.45 & 2.02 & 2.85 \\
Living with spouse and children & 3.21 & 4.56 & 6.33 \\
Living with parents & 2.23 & 0.49 & 0.58 \\
Others & 7.23 & 6.47 & 5.56 \\
Total & 100.00 & 100.00 & 100.00 \\
\hline
\end{tabular}

Source: Computed from the data collected by the 2006 One-per-Thousand Floating Population Survey in Beijing.

consisting of older people and their grandchildren grew rapidly from 1990 to 2000 (Wang 2006).

The great impact of migration on household formation is further indicated by the composition of migrants' households in the place of destination. Table 5 provides information on residential patterns for migrants who lived in Beijing in 2006. According to these statistics, more than 40 per cent of surveyed migrants lived alone. Even among married migrants, those living alone accounted for 22.3 per cent. Although living with spouses increased slightly in recent years in comparison with in the past, there were still about one-third of married migrants whose spouses lived elsewhere. Leaving children behind at the place of origin was very common. Fewer than 10 per cent of migrant parents lived with their children, despite the fact that more than half of those who had left the children behind stated that they wished they could take their children with them.

Residential patterns of this kind have significantly affected the family life of migrants and their family members. This has both a profound impact on the society and considerable policy implications.

Many migrants have spent years working in areas far from their homes. One of their motivations was to bring a better life and future to their children. While this has been partly achieved thanks to their relatively high income in comparison with their non-migrant counterparts, the fact that many of them left their children behind has also resulted in an ironic situation: a large number of migrants' children growing up in the family without the presence of their parents. Many of these children have been taken care of by their grand parents and not seen their parents for years. For example, the migrant survey conducted in Beijing in 2006 revealed that migrants who left their children behind had on average stayed in Beijing for 4.8 years, and many of them had not seen their children for a very long time. It is perhaps the first time in Chinese history that so many children have lived through their early childhood without their parents' presence at home. This could have a huge impact on their development.

Another ironic outcome brought about by the rapid increase in migration is the change in age composition and family support for the elderly in rural areas. Because of the lack of a pension and social security system, old people in China's rural areas 
depend more on their children for support than do their urban counterparts. For this reason, the government has implemented different family planning policies and allowed many rural couples to have two children. The out-migration of working-age population, however, has considerably reduced the number of caregivers in rural areas and left a large number of old people living in 'empty-nest' homes. Many young people moved to cities and provided care to the elderly while they left their own old parents behind. As revealed by the 2000 census, the proportion of people aged 60 or over in households with migrants living elsewhere was 12.6 per cent, which was higher than the 10.8 per cent recorded in the national population. Because their migrant children worked elsewhere, old people often assumed more responsibilities such as doing farm work, taking care of grandchildren and other household chores. Many of the elderly felt lonely and hoped to have more contact with their children. Because most migration-split households were in rural areas, especially those in less developed provinces such as Jiangxi and Anhui, the impact of the out-migration of young people on family support for the elderly was more pronounced in these places. Nonetheless, despite the negative effects listed above, many old people who were left behind by their migrant children were satisfied with their life, compared with those who had no migrant children working in the city. They were generally better-off financially than those who did not receive the remittances which were often sent back by young migrants. ${ }^{16}$ For this reason many old people hoped their children could migrate to cities and find a job there.

The third major impact of increasing migration on family life is the long-term separation between many husbands and wives. Separation of this kind was not uncommon even in the past, but it has reached a new level because of the fast-growing migration in recent years. This, combined with changes in people's attitudes and behaviour regarding marriage and sex, has been leading to great changes in marriage patterns. Chinese marriage has now become less stable in comparison with in the past. Rising divorce rates and extramarital affairs have been recorded in many areas in recent years (Zhai and Duan 2006; Zhang and Gu 2007; Peking Daily 2007).

\section{Conclusions}

China has gone through many profound political, social, economic and demographic changes over the last six decades, which have greatly transformed Chinese society and significantly influenced household formation and composition. Changes in Chinese households have not followed a simple linear trajectory, but shown considerable fluctuations. Driven by land reform, a drastic increase in the total number of households and a sharp reduction in the mean size of households were recorded in the early years of the People's Republic. Between the early 1950s and early 1970s, China maintained a high fertility rate (except during the period of the Great Famine) which was partly promoted by the pronatalist political ideology, favourable social institutions and economic systems. During this period, Chinese households generally became larger than in the early 1950s. Nonetheless, a recent case study has reported that in the 1950s and 1960s changes in household composition were towards nuclearization in the area under investigation (Wang 2007). Whether a similar trend also existed in other parts of China is undoubtedly an important question and deserves further investigation.

Two major changes took place in China in the 1970s. First, a nationwide family 
planning campaign was launched and this led to a rapid fertility reduction. Second, the government started its radical reform which brought about many unprecedented political, social and economic changes. These transformations have not only played a key role in promoting China's recent economic growth, but also exerted a profound impact on kinship structure and household composition. Because of the sharp fertility decline, the number and types of kin available to each individual have been falling considerably in comparison with those under the previous high-fertility regime. This will inevitably influence family support for the elderly in the future. Despite that, however, the proportion of old people having surviving children may still be higher than under the high-mortality regime of historical China. Because of the recent increase in rural-urban migration, China has also had a large increase in the number of migration-split households, those consisting of only old people and their grandchildren, or one of a couple with or without children, or an 'empty nest' of old people in particular. Many of these changes have already become major forces that affect household formation and family life in contemporary China.

\section{Acknowledgments}

This study was partly supported by a research grant provided by Ministry of Education of China (Grant No. 06JJD840016). We thank the anonymous reviewers for their valuable comments and suggestions.

\section{Notes}

1 In his influential article, 'Two kinds of pre-industrial household formation system', Hajnal (1983) suggested that the joint family system, which was characterized primarily by early marriage and patrilocal residential pattern of the newly married, typified the experience in historical China. Hanley and Wolf (1985) also showed that, differing from in pre-industrial Japan where a stem family system was widely followed, the joint family system was predominant in traditional Chinese society.

2 The figure was computed from the data provided in the survey reports and research papers reprinted in Collections of Social Surveys in the Republic Period (Population Volume) (Li et al. 2004). The mean household size in all populations under investigation was 4.9 persons per household or greater except in a small population in Shaowu reclamation area, Fujian, where the mean size of households was 2.77 .

3 No household data were available for years 1948 to 1952. The population total reached 541.7 million in 1949, indicating an annual growth rate of 8.1 per cent for both 1948 and 1949.

4 For further discussion on land reform, see Schran (1969: 13-27).

5 In addition to the statistics listed in Table 1, similar data were provided by other researchers. See Li (1933: 137-139), Qiao (1931: 270-271), and Feng (1933: 18). Wang (2003) also found that the complexity of household structure was closely related to land holding and broadly related to social classes in the villages he studied.

6 See Central Government of the People's Republic of China, The Law of Land Reform of the People's Republic of China (1950), Article 13 (1), p. 644.

7 See People's Government of Beijing (1950). For more examples, see The Regulations of Land Reform in Henan Province (1950), Methods of Land Reform in Dai Autonomous Region of Yunan Province (1955), and Methods of Democratic Reform in Liangshan Yi Autonomous Region of Sichuan Province (1956). The authorities who issued these documents are not available. These documents can be found in Selected Historical Documents of China's 
Land Reform, edited by Editorial Committee of Selected Historical Documents of China's Land Reform and Research Institute of Economics of CASS (1988).

8 For further discussion on the 'public mess dining halls' and their consequences, see Peng (1987: 663-665).

9 In urban areas, while some commodities were distributed in a similar way, children were largely supported by their parents' income, and the economic system was less favourable to childbearing.

10 These figures were likely to have been affected by underregistration of deaths, but even according to more conservative estimates, the life expectancy still reached about 50 in 1957, 61 in 1970 and 65 in 1981 (Banister 1987).

11 Among censuses and surveys conducted in recent years, only the 2006 fertility survey reported a TFR that was notably higher than that recorded by others. Scholars are still in the process of examining this unexpected result.

12 In this study, we consider only the relatives who are linked through blood or marriage.

13 Although the process of simulating kinship structure is very complex, it can be handled effectively through computer microsimulation. For technical details of computer microsimulation and the CAMSIM system, see Smith (1987) and Smith and Oeppen (1993).

14 CAMSIM uses an egocentric approach. To simulate the number and types of kin available to an individual, the system starts by simulating that individual and his (or her) demographic history. This individual is treated as the central figure in his (or her) kin set. For more details, see Smith (1987); Smith and Oeppen (1993).

15 In his previous studies, Zhao simulated kinship structure under various different demographic regimes, which include one similar to that existing in China in the 1930s and one similar to that in China in the 1960s. Those who are interested in these results or in comparing these results with those presented in this paper, see Zhao 1993, 1998.

16 According to the migrant survey conducted in Beijing in 2006, 44 per cent of the migrant workers sent remittances back to their homes in 2005, with an average amount of 4,547 Yuan. In that year, the average income in rural China was only 3,255 Yuan.

\section{References}

Banister, J. 1987. China's Changing Population. Stanford: Stanford University Press.

Barclay, G.W., A.J. Coale, M.A. Stoto and T.J. Trussell. 1976. A reassessment of the demography of traditional rural China. Population Index 42: 606-635.

Cai, Y. 2005. Assessing fertility levels in China using variable-r method. Paper presented at the Annual Meeting of the Population Association of America, Philadelphia.

Central Government of the People's Republic of China. 1950. The Law of Land Reform of the People's Republic of China. Pp. 642-645 in Editorial Committee of China's Land Reform and Research Institute of Economics of CASS (eds), Selected Historical Documents of China's Land Reform. Beijing: Defence University of People's Liberation Army (in Chinese).

Cohen, M.L. 1976. House United, House Divided: The Chinese Family in Taiwan. New York: Columbia University Press.

Editorial Committee of Selected Historical Documents of China's Land Reform and Research Institute of Economics of CASS (eds). 1988. Selected Historical Documents of China's Land Reform. Beijing: Defence University of People's Libration Army (in Chinese).

Editorial Committee of Almanac of China's Population. 2005. Almanac of China's Population 2004. Beijing: Institute of Population and Labour Economic, CASS.

Editorial Committee of Almanac of China's Population. 2006. Almanac of China's Population 2005. Beijing: Institute of Population and Labour Economic, CASS.

Feng, H. 1933. References on Chinese Rural Economy (Part One). Huashi Publishing House (in Chinese). 
Freedman, M. 1979. The Study of Chinese Society: Essays by Maurice Freedman. Stanford: Stanford University Press.

Guo, Z. 2004. Study for fertility of China in the 1990s. Population Research 28: 10-19 (in Chinese).

Hajnal, J. 1983. Two kinds of pre-industrial household formation system. Pp. 65-104 in R. Wall, J. Robin and P. Laslett (eds), Family Forms in Historic Europe. Cambridge: Cambridge University Press.

Hanley, S.B. and A. Wolf (eds). 1985. Family and Population in East Asian History. Stanford: Stanford University Press.

Huang, R. and Y. Liu. 1995. Mortality Data of China Population. Beijing: Data User Service, CPIRC (in Chinese).

Lang, O. 1946. Chinese Family and Society. New York: Yale University Press.

Lee, J. and C. Campbell. 1998. Headship succession and household division in three Chinese banner serf populations, 1789-1909. Continuity and Change 13: 117-141.

Lee, J. and J. Gjerde. 1986. Comparative household morphology of stem, joint, and nuclear household systems: Norway, China, and the United States. Continuity and Change 1: 89-111.

Li, J. 1933. A General Social Survey of Ding Xian. Chinese Promotional Society for People's Education (in Chinese).

Li, W., M. Xia and X. Huang (eds). 2004. Collections of Social Surveys in the Republic Period (Population Volume). Fuzhou: Fuzhou Education Publishing House (in Chinese).

Liao, L. 1952. The great victory of the three-year land reform. Pp. 841-843 in Editorial Committee of China's Land Reform and Research Institute of Economics of CASS (eds), Selected Historical Documents of China's Land Reform. Beijing: Defence University of People's Liberation Army (in Chinese).

Liu, S. 1950. Report on the land reform. Pp. 633-640 in Editorial Committee of China's Land Reform and Research Institute of Economics of CASS (eds), Selected Historical Documents of China's Land Reform. Beijing: Defence University of People's Liberation Army (in Chinese).

Ma, X. 1988. Changes in Chinese household size and structure. Pp. 343-374 in Dixin Xu (ed), Population in Modern China. Beijing: China's Social Science Publishing House (in Chinese).

Ma, X. 1990. Changes in family and population reproduction in China. Pp. 58-81 in Yi Zeng, Chunyuan Zhang and Songjian Peng (eds), Changing Family Structure and Population Aging in China. Beijing: Peking University Press.

National Bureau of Statistics of China. 2006. China Statistical Yearbook 2006. Beijing: China Statistics Press.

Peking Daily. 2007. China's family morality survey: one third of the respondents accept extramarital affairs. <http:// news.eastday.com/c/20070611/u1a2899656.html> Accessed July 2008.

Peng, X. 1987. Demographic consequences of the Great Leap Forward in China's provinces. Population and Development Review 13: 639-670.

People's Government of Beijing. 1950. Report of land reform in Beijing rural areas. Pp. 681-686 in Editorial Committee of China's Land Reform and Research Institute of Economics of CASS (eds), Selected Historical Documents of China's Land Reform. Beijing: Defence University of People's Liberation Army (in Chinese).

Qiao, Q. 1931. A study of 143 rural households in Qing Yuan county of Shanxi. Pp. 263-299 in Chinese Sociology Society (ed.), China's Population. Shanghai: World Press (in Chinese).

Retherford, R. D., M. K. Choe, J. Chen, X. Li and H. Cui. 2005. Fertility in China: how much has it really declined? Population and Development Review 19: 57-84.

Rural Reconstruction Committee of Administrative Council. 1934. A Social Survey in Rural Zhejiang. Shanghai: Commercial Press.

Scharping, T. 2005. Chinese fertility trends 1979-2000: a comparative analysis of birth numbers and school data. Population Research 4: 1-12 (in Chinese). 
Schran, P. 1969. The Development of Chinese Agriculture, 1950-1959. Urbana: University of Illinois Press.

Smith, J. 1987. The computer simulation of kin sets and kin counts. Pp. 249-266 in J. Bongaarts, T. Burch and K. Watcher (eds), Family Demography: Methods and Their Applications. Oxford: Clarendon Press.

Smith, J. and J. Oeppen. 1993. Estimating numbers of kin in historical England using demographic microsimulation. Pp. 280-317 in D. Reher and R. Schofield (eds), Old and New Methods in Historical Demography. Oxford: Clarendon Press.

Wang, D. 2000. Complex households, a fading glory: household formation during the collective period in the People's Republic of China. Journal of Family History 25: 527-544.

Wang, Y. 2000. The Study of 18th Century Chinese Families. Beijing: Law Publishing House (in Chinese).

Wang, Y. 2003. The study of changes in household composition in north China. Social Sciences in China 4: 93-108 (in Chinese).

Wang, Y. 2006. A comparison of changes in the modern Chinese family structure between urban and rural areas. Society 3: 118-136 (in Chinese).

Wang, Y. 2007. An analysis on nuclearization of Chinese rural families. Chinese Journal of Population Science 5: 36-48 (in Chinese).

Wolf, A. and C.-S. Huang. 1980. Marriage and Adoption in China, 1845-1945. Stanford: Stanford University Press.

Yao, X. 1995. Fertility Data of China. Beijing: Data User Service, CPIRC (in Chinese).

Yao, X. and H. Yin. 1994. Basic Data of China's Population. Beijing: Data User Service, CPIRC (in Chinese).

Yu, X. and Z. Xie. 2000. Studies on China's fertility level. In X. Yu and Z. Xie (eds), Population and Development in China: Review and Prospect. Beijing: People Publishing House (in Chinese).

Zha, R. 1999. A Century of Demography in China. Beijing: Beijing Publishing House (in Chinese).

Zhai, Z. 2000. China's population policy in the 1950s: a review and reappraisal. China Population Science 1: 17-26 (in Chinese).

Zhai, Z. and C. Duan. 2006. China's Migration at the Turn of the Centuries. Beijing: China's Population Publishing House.

Zhang, G. and B. Gu. 2007. Recent changes in marriage patterns. Pp. 124-139 in Z. Zhao and F. Guo (eds), Transition and Challenges: China's Population at the Beginning of the 21st Century. Oxford: Oxford University Press.

Zhang, G. and Z. Zhao. 2006. Reexamining China's fertility puzzle: data collection and quality over the last two decades. Population and Development Review 32: 293-321.

Zhang, L. 1931. A survey of 481 households in Jiangning county. In China's Sociology Society (ed.), China's Population. Shanghai: World Press (in Chinese).

Zhao, Z. 1993. Household and kinship in recent and very recent Chinese history. Ph.D. thesis, Cambridge University.

Zhao, Z. 1998. Demographic conditions, microsimulation, and family support for the elderly: past, present and future in China. Pp. 259-279 in P. Horden and R. Smith (eds), The Locus of Care: Families, Communities, and Institutions in History. London: Routledge.

Zhongxishe. 2006. China's migrants have reached more than 10 per cent of the population and close to 150 million. <http:/ / www.china.com.cn/news/txt/2006-10/29/ content_7287862. htm> Accessed July 2008. 